Research article

\title{
DETECTION OF HUMORAL AND CELLULAR IMMUNE RESPONSES IN BUFFALOES NATURALLY INFECTED WITH SARCOCYSTOSIS WITH RISK FACTOR ASSESSMENT
}

\author{
EMAN E. El Shanawany", SOMIA A. Nassar, EMAD Beshir Ata \\ Department of Parasitology and Animal Diseases, National Research Centre, El Bhooth St, Dokki, post \\ pox 12622, Giza, Egypt
}

(Received 07 March, Accepted 08 July 2019)

\begin{abstract}
Sarcocystosis is a silent, parasitic disease which affects various animal species and causes significant economic losses. It is caused by a number of different intracellular Sarcocystis spp. This study was aimed to detect the host humoral and cellular immune response due to natural infection. Adding to the determination of the infection rate in Monufia Governorate, Egypt. A total number of 127 Egyptian buffaloes (Bubalus bubalis); 30 males and 97 females between 2-11 years of age were examined during 2018. An infection rate of $74 \%(94 / 127)$ was detected by macroscopic examination. The old age females were found to be at a high risk of $90.7 \%$ (88/97) in comparison with the young males $20 \%(6 / 30)$. Immunologically, the cellular and humoral immune response was determined using ELISA. A marked down-regulation of the proinflammatory Th-1 cytokine (IFN- $\gamma$ ) and up-regulation of the anti-inflammatory Th-2 cytokine (IL-5) adding to a high level of $\operatorname{IgG}$ and $\operatorname{IgE}$ were detected in the infected animals compared to the non infected ones. The local cellular immune response in the infected tissues was characterized by an accumulation of mixed inflammatory cells, granuloma formation, eosinophilic infiltration, muscular edema, and necrotic degeneration. In conclusion, the Sarcocystis infection rate in the naturally infected buffaloes in Monufia Governorate was high. This is the first study to provide a fundamental insight into the immune profile in buffaloes infected with Sarcocystis spp. So, it will provide valuable insights to develop novel effective vaccines in future studies. Moreover, sensitive and specific tools should be established for the accurate diagnosis of this disease in the different Egyptian governorates through well-structured serological surveys.
\end{abstract}

Key words: Sarcocystosis, Egypt, risk factors, histopathology, immune response, cytokines

\section{INTRODUCTION}

Sarcocystosis is a common parasitic disease caused by an intracellular coccidian parasite belonging to the phylum Apicomplexa with two obligate hosts; a carnivorous definitive host and an omnivorous or herbivorous intermediate hosts including: buffaloes,

\footnotetext{
*Corresponding author: e-mail: ee.elshanawany@hotmail.com
} 
cattle, sheep, and camels [1]. There are no marked clinical signs for sarcocystosis. However, it may lead to significant economic losses in the form of abortion, reduced milk yield, neurologic signs, and loss of weight. Moreover, down-regulation of the meat quality, decreased wool and fiber production adding to its zoonotic importance $[2,3]$. Sarcocystosis has a worldwide distribution with a high prevalence rate both in rural and developed areas [4]. The morbidity and mortality rates depend on multiple risk factors including; the affected species, the host immune status, viability of the sporocysts in the environment, and the hygiene system on the farm $[5,6]$.

In Egypt, high prevalence rate of Sarcocystis spp. infection was recorded among buffaloes with great variations among species and localities $[7,8]$. The most common Sarcocystis spp. were S. fusiformis and S. levinei with a high prevalence rate of $78.9 \%$ [9]. In addition, the microscopic zoonotic $S$. hominis and $S$. cruzi cysts were also detected in some buffaloes [10].

Only a few studies have discussed the host's immune response against Sarcocystis spp. From the reported cases, it was obvious that infection elicits a strong eosinophilic and $\mathrm{T}$ cell-mediated response [11]. In vivo, experimental infection results suggested that $S$. neurona and $S$. calchasi might be able to down-regulate the interferon- $\gamma$ (IFN- $\gamma$ ) signaling pathway $[12,13]$. It was suggested that Sarcocystis spp. may have similar evasion strategies to Toxoplasma gondii, as the well-studied apicomplexan parasite which showed an interference with the IFN- $\gamma$ signaling pathway $[14,15]$. The T helper cell (Th) Th-1/ Th-2 paradigm is important in the pathogenesis of Sarcocystis infection [13]. It was recorded that, different parasitic infections were characterized by the production of $\mathrm{IgE}$ antibodies which accompanied with esinophilia. There is a lack in the studies concerning the level of immunoglobulin ( $\mathrm{Ig}$ ) $\mathrm{E}$ and $\mathrm{IgG}$ in buffaloes infected with Sarcocystis spp. Accordingly, understanding the cellular and humoral immune responses will provide a new insight that will help in the development of immune-modulatory therapeutic approaches and new vaccines against this economically important parasite. Hence, the aims of the current study were detecting of the infection rate in buffaloes naturally infected with sarcocystosis, investigation of the immune response in the form of histopathological examination, detection of serum cytokines; INF- $\gamma$ and interleukin (IL)-5 representing the pro-inflammatory Th-1 and the anti-inflammatory Th-2 responses respectively, and the humoral $\operatorname{IgG}$ and $\mathrm{IgE}$ responses.

\section{MATERIALS AND METHODS}

\section{Ethical approval}

All of the experiments were carried out according to the recommendations and guidelines of the ethical committee of the National Research Centre (NRC) number $(18 / 200)$. 


\section{Study area and samples collection}

A total number of 127 Egyptian buffaloes (Bubalus bubalis), thirty males aged between 2-4 years and 97 females aged between 5 and 11 years were examined in Shibin El Kom abattoir, Monufia Governorate during 2018. Fresh tissue samples (each 30-50 g) were collected from the esophagus and skeletal muscles and examined by the naked eye during the meat inspection process for the detection of macroscopic forms of Sarcocystis spp. The representative serum samples were previously collected. The selected animals were examined for other parasitic infections through fecal examination [16].

Serum samples from one week old calves on private buffalo farms were tested by enzyme-linked immunosorbent assay (ELISA) and found to be negative for sarcocystosis were used as a negative control in the immune profile experiments.

\section{Histopathological studies}

About $1 \mathrm{~cm}$ long pieces of tissues were fixed in 10\% neutralized buffered formalin. Sections of muscle samples were stained by Ehrlich's Hematoxylin and Eosin for the analysis of the local immunological reaction in the infected tissues and for the histological identification of Sarcocystis spp. [17].

\section{Antigen preparation}

Sarcocystis fusiformis bradyzoites antigen was prepared. Briefly, the macroscopic cysts were collected and washed several times to remove the attached skeletal tissues, followed by maceration of the wall until a cream color suspension was formed. The suspension was homogenized in phosphate buffer saline (PBS) pH 7.2 using a manual homogenizer followed by centrifugation for $10 \mathrm{~min}$ at $14000 \mathrm{rpm}$ at $4{ }^{\circ} \mathrm{C}$. The resulting supernatant was collected as aliquots and stored at $-20^{\circ} \mathrm{C}$ [18]. The total protein content was determined according to the method described by Lowry et al. [19].

\section{Determination of the total IgG}

An indirect ELISA was performed to detect the level of $\mathrm{IgG}$ antibodies against Sarcocystis infection in the tested sera according to Morsy et al. [18]. Briefly, wells in ELISA microtitre plates were coated with the prepared Sarcocystis bradyzoite antigen at a concentration of $10 \mu \mathrm{g} / \mathrm{ml}$, the serum samples dilution was 1:100 meanwhile the antibovine IgG horseradish peroxidase (Sigma chemical co., USA) was diluted to 1:1000. The optical density was measured by ELISA reader (Bio-Teck, Germany) at $450 \mathrm{~nm}$ wavelength. The cut off values were calculated [20].

\section{Determination of the total IgE}

The $\mathrm{IgE}$ level in the examined serum samples was determined by a commercial sandwich ELISA kit (Bioneovan Co., China). The concentration of IgE was calculated 
using a standard curve obtained from the known concentration of the standard IgE included in the kit.

\section{Determination of cytokines (IL-5 and INF- $\gamma$ )}

ELISA was performed to determine the levels of serum IL-5 and INF- $\gamma$ cytokines concentrations in the tested samples using the commercially available ELISA kits (Bioneovan Co., China). A standard curve was obtained from a known concentration of the cytokine standard included in each assay according to the manufacturer instructions.

\section{Statistical analysis}

The data were analyzed using one-way analysis of variance (ANOVA). Results were expressed as mean \pm standard deviation (SD) and values of $\mathrm{p}>0.05$ were considered statistically insignificant, while those of $\mathrm{p}<0.05$ and $\mathrm{p}<0.01$ were considered statistically significant and highly significant, respectively. The curves were represented by MEDCALC easy-to-use statistical software.

\section{RESULTS}

\section{Infection rate detection and risk factors}

The macroscopic examination during regular meat inspection at the abattoir disclosed that 94 out of the 127 examined animals had macroscopic sarcocystosis with an overall $74 \%$ infection rate (Table 1$)$.

Table 1. Overall infection rate of buffaloes naturally infected with Sarcocystis spp. in relation to age and sex of the tested animals in Shibin El Kom abattoir, Monufia Governorate

\begin{tabular}{cccc}
\hline \multirow{2}{*}{$\begin{array}{c}\text { Age } \\
\text { (Year) }\end{array}$} & $\begin{array}{c}\text { Number of examined } \\
\text { animals (Gender) }\end{array}$ & Number & Percentage \% \\
\hline $2-4$ & 30 Males & 6 & $20.0 \%$ \\
$5-8$ & 34 Females & 28 & $82.3 \%$ \\
Older than 8 & 63 Females & 60 & $95.2 \%$ \\
Total & 127 & 94 & 74 \\
\hline
\end{tabular}

Regarding the sex as a risk factor, it was found that the percentage of infected males 20\% (6/30) was lower than for the infected females $90.7 \%$ (88/97) (Table 1). Concerning the age as a risk factor, the obtained results indicated that the percentage of infected animals increased with age. The infection rate was $20 \%(6 / 30)$ in the $2-4$ years group, $82.3 \%(28 / 34)$ in the $5-8$ years group, and $95.2 \%(60 / 63)$ in animals over 8 years of age (Table 1 ). 


\section{Morphological identification of the cysts}

The predilection sites of the infection were in the deep muscular layer of the mandibular and esophageal tissues. The cysts were milky white opaque in color with a fusiform shape. Morphologically, the size of the macroscopic cysts ranged from 0.5$3.5 \times 0.3-0.8 \mathrm{~cm}$. Histophathologically, the size of cyst wall characterized by thick cyst wall $1.5-4 \mu \mathrm{m}$, the size of bradyzoites ranged from 8.4 to $15.6 \times 2.5$ to $5.4 \mu \mathrm{m}$. The macrocytic cyst was characterized as $S$. fusiformis based on the size of cyst, bradyzoites and thickness of the cyst wall (Fig. 1,2).

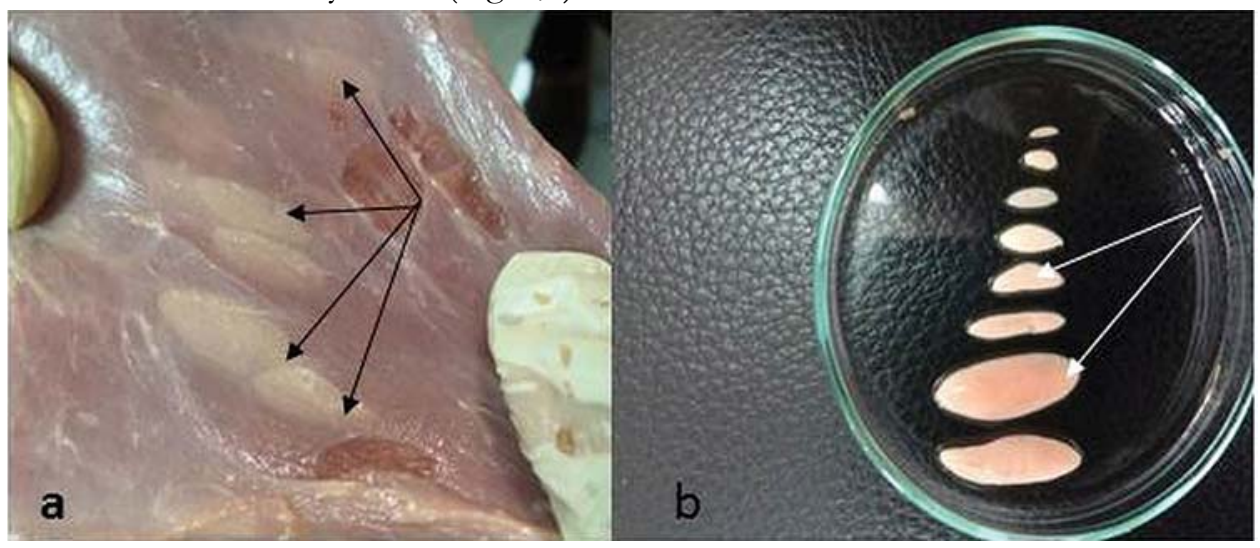

Figure 1. Esophagus of a buffalo infected with macroscopic S.fusiformis. A) Macroscopic picture of sarcocystosis showing S.fusiformis (macrocysts) underneath the serosa surface of skeletal muscles. B) Macroscopic picture showing fusiform-shaped sarcocysts (S.fusiformis) measuring about $0.5-8.5 \mathrm{~mm}$ length and $0.5-3 \mathrm{~mm}$ width extracted from esophagus.

\section{The local cellular immune response}

Histologically, buffalo's esophagus and mandibular tissues infected with $S$. fusiformis have a cellular immune reaction characterized by an accumulation of mixed inflammatory cells, eosinophilic infiltration, muscular edema, and necrotic degeneration, adding to lymphocyte and plasma cells infiltration (Fig. 3).

\section{Cytokine profile}

In order to determine the cellular immune response due to Sarcocystis spp. infection, the levels of IFN- $\gamma$ (Th-1) and the IL-5 (Th-2) cytokines were evaluated using ELISA. The obtained results showed a marked down-regulation of IFN- $\gamma$ and up-regulation of IL-5 levels in the infected animals in comparison with the non infected animals (Fig. 4).

\section{Detection of specific IgG and IgE}

The total IgG and IgE levels were determined to detect the humoral antibodies responses to sarcocystosis. The $\mathrm{IgG}$ level was high in all infected animals in comparison 
with the non infected ones. The ELISA based IgG level showed an infection rate of $92 \%$ (Fig. 5). Infection with $S$. fusiformis resulted in high level of $\operatorname{IgE}$ antibodies when compared with healthy non infected buffaloes (Fig. 6).

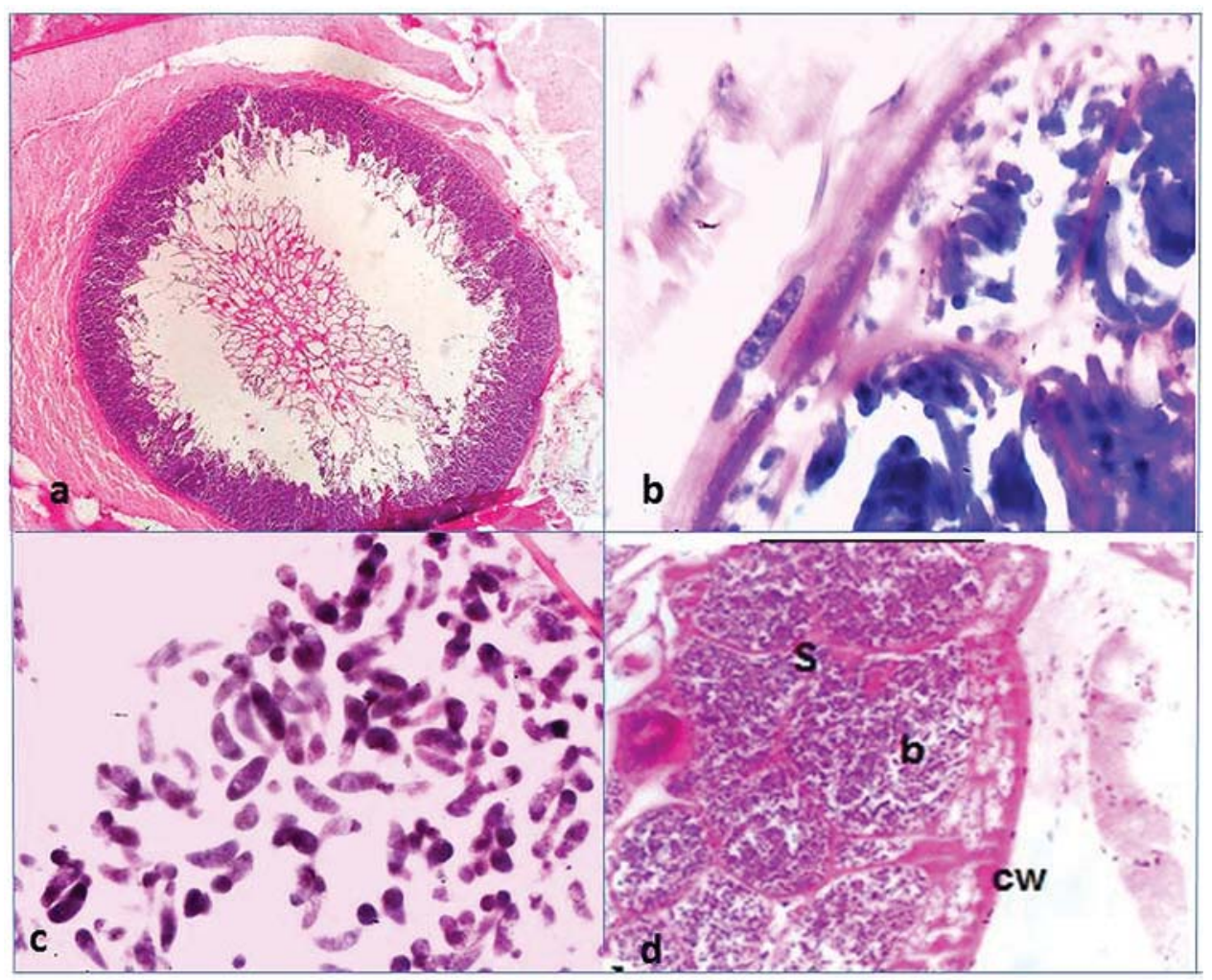

Figure 2. Histological section of a mature $S$. fusiformis cyst. A) Cross section of the $S$. fusiformis cyst isolated from an infected buffalo's esophagus indicated condensing of bradyzoites at the periphery then decreasing towards the center. B) Thick cyst wall with $2-4 \mu \mathrm{m}$ size. C) S.fusiformis bradyzoites size was 8.4 to $15.6 \times 2.5$ to $5.4 \mu \mathrm{m}$. D) Longitudinal section in $S$. fusiformis cyst, a smooth, thick cyst wall $(1.5-4 \mu \mathrm{m})(\mathrm{CW})$ was surrounding the cyst. Fine septa (S) originated from the inner layer dividing the cavity of the cyst into different size diverse chambers, those were packed with bradyzoites (b). H\&E (x100). 

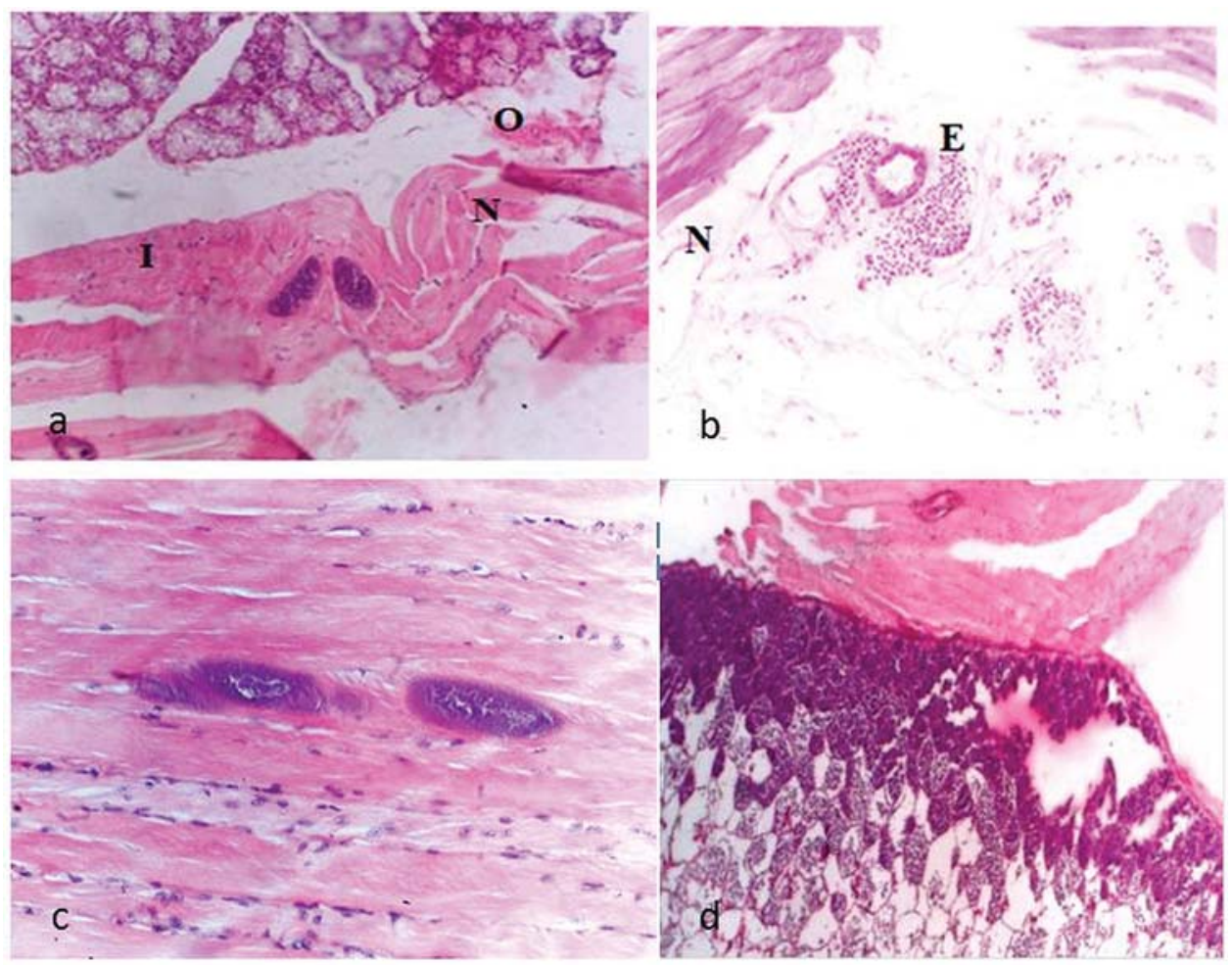

Figure 3. Photomicrograph of the longitudinal section in the muscles of the esophagus. A) The mandibular tissue section of buffaloes infected with $S$. fusiformis showed intense inflammatory reactions (I) necrotic degeneration in muscles $(N)$ and muscles edema $(\mathrm{O})$ (H\&E, 200X). B) A section in an infected buffaloes esophagus showed intense eosinophilic (H\&E, 200X) (E) and moderate lymphocytic infiltration, and necrotic muscles. C) and D) Degeneration in the esophageal muscle with inflammatory cells infiltration; eosinophils, macrophage, and lymphocytes (H\&E, 200X).
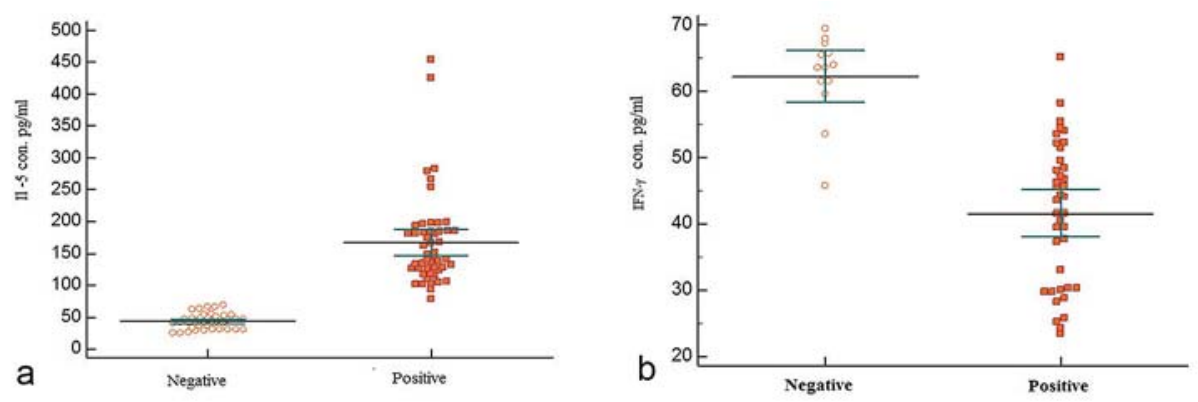

Figure 4. Cytokines profile of Il-5 (A) and INF- $\gamma$ (B) in the serum of buffaloes infected with S. fusiformis compared with non infected animals. The figure illustrates the down regulation of IFN- $\gamma$ and up-regulation of IL-5 levels in naturally infected animals in comparison with the non infected ones. Positive $=$ buffaloes infected with sarcocystosis, negative $=$ non infected buffaloes. 


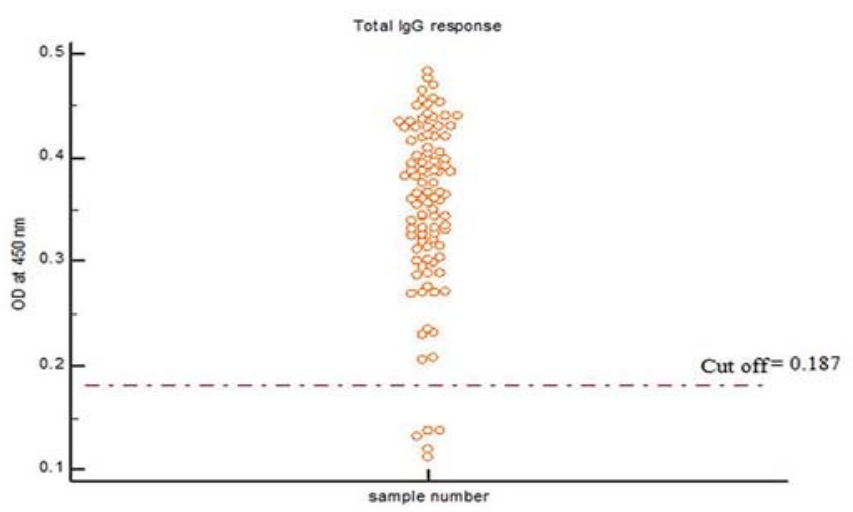

Figure 5. Detection of specific IgG antibodies against $S$. fusiformis by ELISA. The cut-off is the mean $\pm 3 \mathrm{SD}$ of negative sera from non infected buffaloes. The figure illustrates the elevation in the level of $\operatorname{IgG}$ within naturally infected animals in comparison with non infected ones.

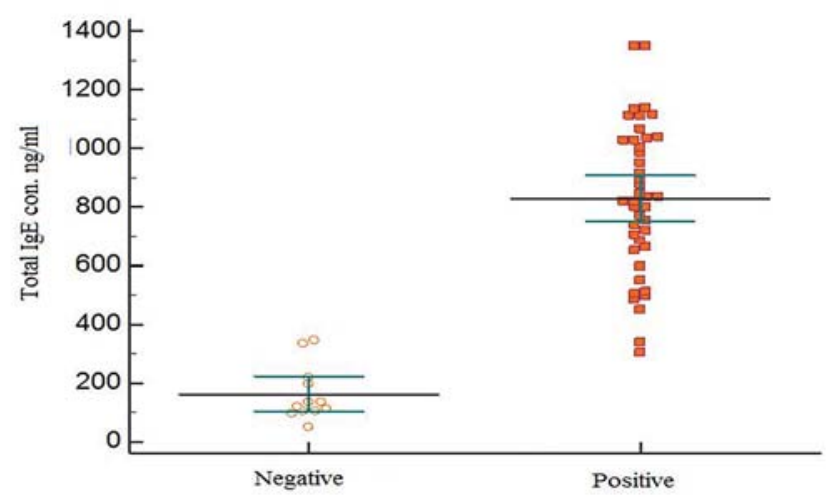

Figure 6. Scattergram represents the intensity of Sarcosystis infection for IgE responses in buffaloes. IgE concentration $(\mathrm{ng} / \mathrm{ml})$ was estimated by ELISA assay in serum samples from Sarcocystis-infected and healthy buffaloes (negative).

\section{DISCUSSION}

Sarcocystosis is a common disease of variant animal species that could lead to weight loss, anaemia, and muscle weakness while severe cases could progress into abortion and or death [21].

The presented results indicated that sarcocystosis was common in water buffaloes (Bublus bubalis) in Monufia Governorate, Egypt with 74\% infection rate. Previous local studies revealed variable infection rate in different Egyptian governorates that varied from $8.3 \%$ in the New Valley [7] and $28 \%$ in Sohag [22]. It is suggested that this low infection rate may be attributed to the arid climatic condition in some governorates 
which is unfavourable for the sporocysts survival. Meanwhile, a high percentage of 69\% was detected in Cairo and Giza [8], 78.9\% in Beni-Suef [9], and 94.4\% in Assiut governorates [10]. Globally, a high prevalence rate was recorded in different countries including China (94\%) [23], and Thailand (100\%) [24]. But, a lower rate of 65\%,66.4\%, and 66.7\% was recorded in Philippines [25], India [26], and Malaysia [27] respectively. It is worth noting that, number of sporocysts disseminated by the definitive host and its ability to survive and counteract the environmental conditions like temperature and humidity are amongst the main determinants of the infection rate $[9,28]$.

Regarding the age as a risk factor, the obtained results showed a marked correlation between the age and the infection rate which increased significantly with the age. It was only $20 \%$ in the group of 2-4 years. However, the groups of 5-8 years and over than 8 years old was $82.3 \%$ and $95.2 \%$ respectively. Similar results were recorded in previous study as low infection rate $30.76 \%$ was found in animals less than 1 year old and $87.32 \%$ was found in 2-6 years old animals [29]. On the other hand, JyothiSree et al. [26] recorded that the infection rate increased with the age with slight variation between the different groups as $65.16 \%$ of $1.5-3$ years old animals and $68.75 \%$ of the 5-8 years old animals were infected. Moreover, $78 \%$ infection rate of animals under 2 years old and $88 \%$ of animals older than 2 years was detected by Oryan et al. [28]. The correlation between the age and the increased infection rate may be attributed to different factors including; increasing the chance of repeated exposition to infection, which result in cysts accumulation gradually in muscle [30], the cysts need longer time to appear macroscopically compared to microscopic cysts [9], close contact with canidae final host [31]. Especially that most of the Egyptian slaughter houses did not have complete securing from entrance of stray dogs which could complete life cycle and encourage spread of infection.

According to the sex of the tested animals, it was found that the infection rate was $90.7 \%$ in females versus $20 \%$ in males. The low percentage of the infected males may be attributed to the animal management system in Egypt, as most of the males were kept only for fattening system and being slaughtered around 2 years old while females were kept for long times for milk production. A previous study reported that higher incidence of sarcocystosis was found in elderly females [7]. On the other hand, It was recorded that, $60.86 \%$ of male versus $79.03 \%$ of female examined animals were infected [29].

Morphometric features of Sarcocystis cyst wall and the size of the cyst are considered the basic criteria for differentiation between Sarcocystis spp [4,32]. The obtained cysts were of S.fusiformis and characterised by milky white opaque colour with fusiform shape measured $0.5-3.5 \times 0.3-0.8 \mathrm{~cm}$. The cyst wall was smooth, thick and measured about $1.5-4 \mu \mathrm{m}$. The obtained result is supported by observation of El-Dakhly et al. [9], El-Seifyet al. [33] where they found that S.fusiformis cyst wall measured 1-3 $\mu \mathrm{m}$ and $2.6-14.5 \mu \mathrm{m}$ respectively. 
Histopathologically, The presented results showed local cellular immune response in buffaloes infected with sarcocystosis that characterized by a granulomatous reaction, muscles oedema, eosinophils, admixed with smaller numbers of lymphocytes infiltration. There are several reports demonstrated the role of the cellular inflammatory response in host protection during sarcocystosis infection [34]. The cellular immune response appeared to be induced by eosinophil chemo-attractant secreted from the sarcocysts during their normal metabolic process. These findings provided a presumption that buffaloes infected with sarcocystis were predisposed to produce $\operatorname{IgE}$ in response to Sarcocystis bradyzoite antigen, and that eosinophile and inflammatory cells represented an abnormal response to sarcocyst degeneration, including a host-dependent, Sarcocystic, type-I hypersensitivity [35,36].

Little information is known about anti-Sarcocystis response profile of the host immune system in comparison with the closely related Apicomplexa like T. gondii and Neospora caninum. To further clarify the effect of Sarcocystis spp. on the host immune response, the serum level of INF- $\gamma$ and IL-5 was measured in the naturally infected buffaloes. The presented results revealed suppression in INF- $\gamma$ (Th1) which results in the differentiation of Th precursors into Th2 lymphocytes which secrete the IL-5 in comparison with non infected animals. Similar down-regulation of IFN- $\gamma$ production was recorded in infection with $S$. neurona and $S$.calchasi $[12,13]$. The natural killer cells which has a major role in IFN- $\gamma$ secretion, absence of these cells during hisopathological examination supported the obtained low level of IFN- $\gamma$ in the tested serum samples. According to previous observations and the results of the presented study, it is plausible to declare that Sarcocystis spp. in general may exhibit an immune evasion strategy that disrupts IFN- $\gamma$ signalling. This disruption in IFN- $\gamma$ production may, similar to T. gondii [37] and N. caninum [38] that could aid Sarcocystis spp. to infect host cells and modulated immune response for surviving within the host. It was reported that the IL-5 cytokine stimulates eosinophil degranulation, production of reactive oxygen species, and exerting a chemotactic effect on these cells [39]. Nickdel et al. [40] discussed that T. gondii infection cause's eosinophilia and increased the level of IL-5, with pathological changes in the small intestine, with a simultaneous reduction in IL-12 and IFN- $\gamma$. Moreover, a biphasic immune responses were characteristic in eosinophilic muscle invasive Sarcocystis infections with a Th1 response during the initial phase while in muscle stage, the Th2 response was abundant [41].

The current study indicated that there was a statically significant increase in the IgG level and $\operatorname{IgE}$ concentration in the naturally infected buffaloes in comparison with the non infected animals. In primary infection with Apicomplexa, the role of $\mathrm{B}$ cells has minor contribution in the protective immunity. However, several studies proved that production of protective, parasite-specific immunoglobulins after infection and recovery will be a result of host infection with these parasites [42]. The current results suggested that the presence of both $\operatorname{IgE}$ and total $\operatorname{IgG}$ responses provide a strong support for their role in the clearance of Sarcocystis infection. High level of IgE will result in Sarcocystis specific type-I hypersensitivity which play an important role in 
pathogenesis of sarcosystosis in buffaloes. The presented result was confirmed by the increase of IL-5 cytokine which develop B-cell proliferation and antibody production $[43,44]$. The obtained results were coincided with the results of Granstrom et al. [36] who proved the presence of $S$. cruzi -specific $\operatorname{IgG}$ and $\operatorname{IgE}$ in eosinophilic myositis lesions in cattle. The presence of $S$. fusiform bradyzoite -specific IgG in infected buffaloes and elevated $\operatorname{IgG}$ values support the a possible role for $\operatorname{IgG}$ in the pathogenesis of sarcosystosis. Moreover, O’Donoghue and Weyreter [45] proved that the infection of sheep with Sarcocystis results in elevation of IgG level.

\section{CONCLUSION}

The current study represented that sarcocystosis infection rate in Monufia Governorate was high (74\%). The old females were in a high risk comparing to the young males. The immune response of the naturally infected buffaloes showed an increase in the IL-5 (Th2) production and down-regulation in INF- $\gamma$ (Th1) which facilitates immune evasion strategy adding to the increase in the parasite reactive $\operatorname{IgG}$ levels adding to the increase in the $\mathrm{IgE}$ level comparing with the non-infected ones. The local cellular immunity of the infected tissues was characterized by eosinophil and lymphocyte infiltration, muscles edema and degeneration. The present study is the first to provide a fundamental insight into the immune profile of naturally infected buffaloes with sarcocystosis. Full understanding of this profile will get a first glance for the development of novel effective vaccines in future studies. Moreover, novel, sensitive, and specific tools should be developed for an accurate diagnosis of this disease.

\section{Acknowledgement}

The authors are grateful to the National Research Centre, Egypt for supporting this work through a research grant (number AR111208).

\section{Authors' contributions}

EEE designed the study and contributed to the experiments conducting, laboratory work analysis and data interpretation, manuscript preparation and writing. EBA contributed in conducting the experiments, the result analysis and in the manuscript preparation. SAN shared in experiments conducting. All authors have read and approved the final version of the manuscript.

\section{Declaration of conflicting interests}

The author(s) declared no potential conflicts of interest with respect to the research, authorship, and/or publication of this article. 


\section{REFERENCES}

1. Fayer R, Esposito DH, Dubey JP: Human Infections with Sarcocystis Species. Clin Microbiol Rev 2015, 28:295-311.

2. Decker Franco C, Schnittger L, Florin-Christensen M: Sarcocystis. Parasit. Protozoa Farm Anim. Pets. Cham: Springer International Publishing; 2018, 103-124.

3. Saeed MA, Vaughan JL, Jabbar A: An update on sarcocystosis in one-humped camels (Camelus dromedarius). Parasitology 2018, 145:1367-1377.

4. Dubey JP, Speer CA, Fayer R: Sarcocystosis of animals and man. Boca Raton, Florida, USA: CRC Press, Inc.; 1989.

5. Savini G, Robertson ID, Dunsmore JD: Viability of the sporocysts of Sarcocystis cruzi after exposure to different temperatures and relative humidities. Vet Parasitol 1996, 67:153-160.

6. Poulsen CS, Stensvold CR: Current status of epidemiology and diagnosis of human sarcocystosis. J Clin Microbiol 2014, 52:3524-3530.

7. Ahmed AM, Elshraway NT, Youssef AI: Survey on Sarcocystis in bovine carcasses slaughtered at the municipal abattoir of El-Kharga, Egypt. Vet World 2016, 9:1461-1465.

8. Nahed G, Reda W, Sara N: Occurrence of zoonotic sarcosporidiosis in slaughtered cattle and buffaloes in different abattoirs in Egypt. Glob Vet 2014, 13:809-813.

9. El-Dakhly KM, El-Nesr KA, El-Nahass E-S, Hirata A, Sakai H, Yanai T: Prevalence and distribution patterns of Sarcocystis spp. in buffaloes in Beni-Suef, Egypt. Trop Anim Health Prod 2011, 43:1549-1554.

10. Metwally AM, Abd Ellah MR, Al-Hosary AA, Omar MA: Microscopical and serological studies on Sarcocystis infection with first report of S. cruzi in buffaloes (Bubalus bubalis) in Assiut, Egypt. J Parasit Dis 2014, 38:378-382.

11. Agholi M, Heidarian HR, Moghadami M, Hatam GR: First detection of acalculous cholecystitis associated with Sarcocystis infection in a patient with AIDS. Acta Parasitol 2014, 59:310-315.

12. Spencer JA, Deinnocentes P, Moyana EM, Guarino AJ, Ellison SE, Bird RC, Blagburn BL. Cytokine gene expression in response to SnSAG1 in horses with equine protozoal myeloencephalitis. Clin Diagn Lab Immunol 2005, 12:644-646.

13. Olias P, Meyer A, Klopfleisch R, Lierz M, Kaspers B, Gruber AD: Modulation of the host Th1 immune response in pigeon protozoal encephalitis caused by Sarcocystis calchasi. Vet Res 2013, 44:10.

14. Shapira S, Speirs K, Gerstein A, Caamano J, Hunter CA: Suppression of NF-kappaB activation by infection with Toxoplasma gondii. J Infect Dis 2002, 185 Suppl:S66-72.

15. Sacks D, Sher A: Evasion of innate immunity by parasitic protozoa. Nat Immunol 2002, 3:1041-1047.

16. Mooney L, Good B, Hanrahan JP, Mulcahy G, de Waal T: The comparative efficacy of four anthelmintics against a natural acquired Fasciola hepatica infection in hill sheep flock in the west of Ireland. Vet Parasitol 2009, 164:201-205.

17. Bancroft J, Stevens A: Theory and practice of histological techniques. 3rd ed. London: Long Man Group Limited; 1993.

18. Morsy TA, Abdel Mawla MM, Salama MM, Hamdi KN. Assessment of intact Sarcocystis cystozoites as an ELISA antigen. J. Egypt. Soc. Parasitol. [Internet]. 1994;24:85-91. Available from: http://www.ncbi.nlm.nih.gov/pubmed/8169453. 
19. Lowry OH, Rosebrough NJ, Farr AL, Randall RJ: Protein measurement with the Folin phenol reagent. J Biol Chem 1951, 193:265-275.

20. Almazán C, Avila G, Quiroz H, Ibarra F, Ochoa P: Effect of parasite burden on the detection of Fasciola hepatica antigens in sera and feces of experimentally infected sheep. Vet Parasitol 2001, 97:101-112.

21. Fayer R: Sarcocystis spp. in human infections. Clin Microbiol Rev 2004, 17:894-902.

22. Khalifa RMA, El-Nadi NAE-FA, Sayed FG, Omran EK: Comparative morphological studies on three Sarcocystis species in Sohag, Egypt. J Egypt Soc Parasitol 2008, 38:599-608.

23. Xiao B, Zhang Y, Yong Z: A survey of sarcosporidios in domestic animals. Chinese J Vet Med 1988, 14:12-14.

24. Muangyai M, Chalermchaikit T: The incidence of Sarcocystis in cattle and buffaloes. Thai J Vet Med 1988, 18: 319-326.

25. Claveria FG, Cruz MJ, Lim RS: Sarcocystis spp infection in Philippine water buffaloes (Bubalus bubalis). Southeast Asian J Trop Med Public Health 2000, 31 Suppl 1:44-47.

26. JyothiSree C, Venu R, Samatha V, Malakondaiah P, Rayulu VC: Prevalence and microscopic studies of Sarcocystis infection in naturally infected water buffaloes (Bubalus bubalis) of Andhra Pradesh. J Parasit Dis 2017, 41:476-482.

27. Latif B, Vellayan S, Heo CC, Kannan Kutty M, Omar E, Abdullah S, Tappe D: High prevalence of muscular sarcocystosis in cattle and water buffaloes from Selangor, Malaysia. Trop Biomed 2013, 30:699-705.

28. Oryan A, Ahmadi N, Mousavi SMM: Prevalence, biology, and distribution pattern of Sarcocystis infection in water buffalo (Bubalus bubalis) in Iran. Trop Anim Health Prod 2010, 42:1513-1518.

29. Mohammad HM: Prevalence of Bovine Sarcocystosis in Babylon province. Kufa J Vet Med Sci 2012, 3:78-83.

30. Taib M, Harhoura K, Aissi M, Chaouadi M, Djouhri Y: Study of the bovine sarcosporidiosis in the slaughterhouses of the North of Algeria: Case of the slaughterhouses of El Harrach (Algiers). Cell Dev Biol 2016, 5:1.

31. Collier L, Balows A, Sussman M. Sarcocystis, Isospora and Cyclospora. In: Gransden, W.R, editor. Sarcocystis, Isospora and Cyclospora. 9th ed. New York: Oxford University Press Inc; 1998, 319-326.

32. Xiang Z, Rosenthal BM, He Y, Wang W, Wang H, Song J, Shen PQ, Li ML, Yang Z: Sarcocystis tupaia, sp. nov., a new parasite species employing treeshrews (Tupaiidae, Tupaia belangeri chinensis) as natural intermediate hosts. Parasitol Int 2010, 59:128-132.

33. El-Seify M, El-Morsey A, Hilali M, Zayed A, El-Dakhly K, Haridy M, Sakai H, Yanai T: Molecular characterization of Sarcocytis fusiformis and Sarcocystis buffalonis infecting water buffaloes (Bubalus bubalis) from Egypt. Am J Anim Vet Sci 2014, 9:95-104.

34. Kimura T: Eosinophilic myositis resulted from Sarcocystis infection in prime marbled beef of japanese black cattle. Vet World 2011, 4:500-502.

35. Granstrom DE, Ridley RK, Baoan Y, Gershwin LJ, Nesbitt PM, Wempe LA: Type-I hypersensitivity as a component of eosinophilic myositis (muscular sarcocystosis) in cattle. Am J Vet Res 1989, 50:571-574.

36. Granstrom DE, Ridley RK, Yao B, Gershwin LJ, Briggs DJ: Immunofluorescent localization of Sarcocystis cruzi antigens, $\operatorname{IgG}$ and $\mathrm{IgE}$, in lesions of eosinophilic myositis in cattle. J Vet Diagn Invest 1990, 2:147-149. 
37. Miller CM, Boulter NR, Ikin RJ, Smith NC: The immunobiology of the innate response to Toxoplasma gondii. Int J Parasitol 2009, 39:23-39.

38. Innes EA, Wright S, Bartley P, Maley S, Macaldowie C, Esteban-Redondo I, Buxton D: The host-parasite relationship in bovine neosporosis. Vet Immunol Immunopathol 2005, 108:29-36.

39. Faccioli LH, Vargaftig B, Medeiros AI, Malheiros A: Cytokines in the modulation of eosinophilia. Mem Inst Oswaldo Cruz 1997, 92:109-114.

40. Nickdel MB, Lyons RE, Roberts F, Brombacher F, Hunter CA, Alexander J, Roberts CW: Intestinal pathology during acute toxoplasmosis is IL-4 dependent and unrelated to parasite burden. Parasite Immunol 2004, 26:75-82.

41. Tappe D, Slesak G, Pérez-Girón JV, Schäfer J, Langeheinecke A, Just-Nübling G, MuñozFontela C, Püllmann K: Human invasive muscular sarcocystosis induces Th2 cytokine polarization and biphasic cytokine changes, based on an investigation among travelers returning from Tioman Island, Malaysia. Clin Vaccine Immunol 2015, 22:674-677.

42. Frölich S, Entzeroth R, Wallach M: Comparison of protective immune responses to apicomplexan parasites. J Parasitol Res 2012, 2012:852591.

43. Swain SL, McKenzie DT, Dutton RW, Tonkonogy SL, English M: The role of IL4 and IL5: characterization of a distinct helper T cell subset that makes IL4 and IL5 (Th2) and requires priming before induction of lymphokine secretion. Immunol Rev 1988, 102:77-105.

44. Takatsu K, Tominaga A, Harada N, Mita S, Matsumoto M, Takahashi T, Kikuchi Y, Yamaguchi N: T cell-replacing factor (TRF)/interleukin 5 (IL-5): molecular and functional properties. Immunol Rev 1988, 102:107-135.

45. O’Donoghue PJ, Weyreter H: Examinations on the serodiagnosis of Sarcocystis infections. II. Class-specific immunoglobulin responses in mice, pigs, and sheep. Zentralbl Bakteriol Mikrobiol Hyg A 1984, 257:168-184.

\title{
DETEKCIJA HUMORALNOG I CELULARNOG IMUNSKOG ODGOVORA KOD BIVOLA SA SARKOCISTOZOM I PROCENA RIZIKA
}

\author{
EMAN E. El Shanawany, SOMIA A. Nassar, EMAD Beshir Ata
}

Sarkocistoza je parazitsko oboljenje kod različitih životinjskih vrsta i dovodi do značajnih ekonomskih gubitaka, izazvano većim brojem intracelularnih uzročnika u okviru Sarcocystis spp. Cilj ove studije je da odredi humoralni i celularni imunski odgovor tokom prirodne infekcije, i na taj način doprinese utvrđivanju stope infekcije bivola u Monufia oblasti (Egipat). Tokom 2018. ukupno je pregledano 127 Egipatskih bivola (Bubalus bubalis); 30 mužjaka i 97 ženki starosti od 2-11 godina. Makroskopski je određena stopa infekcije od 74\% (94/127). Starije ženke su bile izložene većem riziku (90,7\%; 88/97) u odnosu na mlade mužjake $(20 \%$; 6/30). Ćelijski i humoralni imunski odgovor je određen ELISA metodom. Kod inficiranih životinja uočena je izražena depresija proinflamatornog Th-1 citokina (IFN- $\gamma$ ) i stimulacija antiinflamatornog Th-2 
citokina (IL-5), zajedno sa višim nivoom IgG i IgE. Lokalni celularni imunski odgovor u inficiranim tkivima je okarakterisan nakupljanjem inflamatornih ćelija, nastankom granuloma, infiltracijom eozinofilima, edemom mišića i nekrozom.

Stopa prirodne infekcije sa Sarcocystis spp. bivola u Monufia oblasti je bila visoka. Ovo je prva studija koja pruža ključni uvid u imunski profil bivola prisodno inficiranih sa Sarcocystis spp. takođe otvara mogućnost razvoja novih efikasnih vakcina. Treba da se razviju osetljive i specifične procedure za preciznu dijagnostiku ove bolesti širom Egipta, pomoću dobro koncipiranih seroloških metoda. 